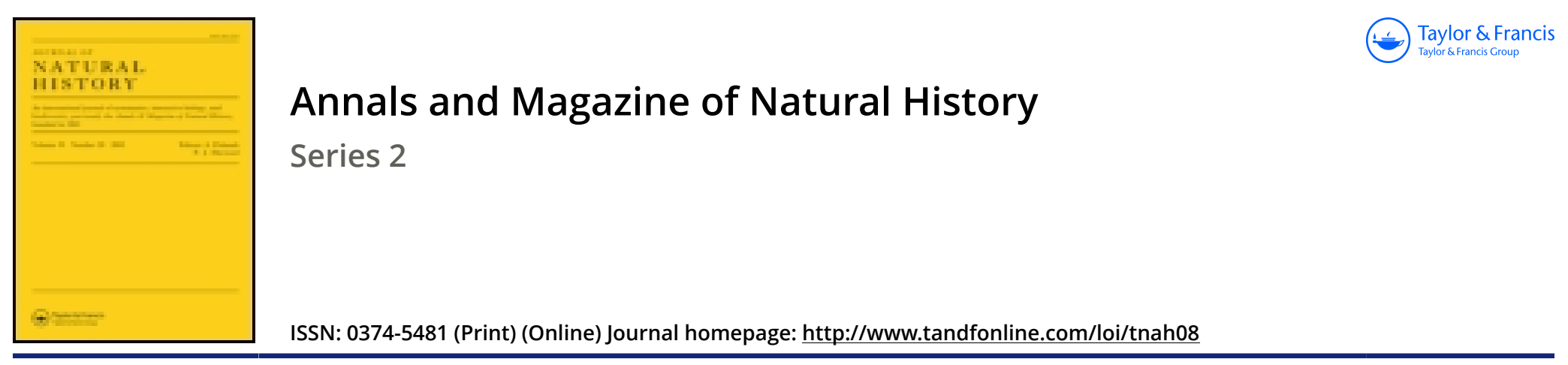

\title{
XLIV.-On the botanical productions of the kingdom of Algiers, followed by a short notice of the supposed manna of the Israelites
}

\section{Giles Munby Esq.}

To cite this article: Giles Munby Esq. (1849) XLIV.-On the botanical productions of the kingdom of Algiers, followed by a short notice of the supposed manna of the Israelites , Annals and Magazine of Natural History, 4:24, 426-435, DOI: 10.1080/03745486009494861

To link to this article: http://dx.doi.org/10.1080/03745486009494861

曲 Published online: 16 Dec 2009.

Submit your article to this journal $\pi$

Џll Article views: 3

Q View related articles $\sqsubset$ 
XLIV.-On the Botanical Productions of the Kingdom of Algiers, followed by a short notice of the supposed Manna of the Israelites. By Grles Munby, Esq.*

Since the occupation by the French in 1830 of the kingdom of Algiers, but little has been done to advance the knowledge of its natural-history productions, and, if we except the 'Travels'of our own countryman Dr. Shaw, who visited Barbary about a century ago, and the 'Flora Atlantica' of Desfontaines, no work has ever been published devoted to the natural history of this country. The vegetation of the coast of Barbary resembles in a great measure that of the Spanish and French shores of the Mediterranean; but although the general features of its flora are the same, many species of plants are found in Barbary which are unknown to the continent of Europe.

A botanist of the North of Europe is struck by the quantity of prickly pears (Cactus Opuntia) and American aloës (Agave americana), which, with a few date-palms scattered here and there, give a tropical appearance to the vegetation. The same feature is however observed on the Spanish coast near Malaga and the southern provinces.

The dwarf palm (Chamarops humilis) is another plant common to both regions, and in Algeria covers immense tracts of country, resembling fields of grass or young corn, as this palm very seldom produces a trunk. They sometimes rise to the height of 20 feet in the neighbourhood of some Marabout or Saint's tomb, which may probably depend on the care taken of them in such a situation. This plant is one of the most useful that the country produces. The leaves are made into baskets, cords, fans, sacks, sleeping mats, \&c. The fibre which surrounds the stalks of the leaves, spun with camels' hair, serves to make the Arab tent. The centre of the plant, consisting of the tender foot-stalks of the leaves and the young flowers and their sheaths, forms one of the principal articles of food for the Arabs during a certain season of the year, and I have seen wandering tribes going about with their donkeys loaded with these roots and no other provision. The fruit ripens in autumn, and is eaten by jackals and by the Arab shepherds ; but although sweet, its astringency renders it unfit for a European palate.

The Cactus Opuntia, called in the country Kermous ensàrah, or Christians' fig, is another plant which furnishes in due season the Arab his nourishment. This fruit ripens in July and continues until the autumnal rains in September or October ; it is

* Communicated by the Author; laving been read before the British Association at the Meeting held at Birmingham, Sept. 12, 1849. 
sweet and very nutritious, although it is apt to disagree with European stomachs, bringing on severe constipation, not from any astringency in the fruit, but probably from a mechanical cause, namely the seeds, which are very numerous, lodging in the colon.

The Agave americana serves to make hedges of, and the flowering stem is much used in constructing huts, but no part of the plant is edible: the fibres of the young leaves make a very durable cordage, and many objects of ornament and utility are made from it by the condamnés militaires, or soldiers condemned to hard labour for infraction of military discipline.

The brushwood which covers the hills in Barbary is principally composed of the following plants : Cytisus spinosus, Pistacia Lentiscus, Quercus coccifer, and many species of Cistus, the most common of which are $C$. heterophyllus, $C$. monspeliensis, $C$. salvifolius, and in certain localities C. ladaniferus and C. albidus. Two species of heath are also common, Erica arborea flowering: in spring, and $E$. multiflora which covers the hills near Algiers and flowers in October and November, Rhamnus Alaternus, Arbutus Unedo, the fruit of which ripens in winter, and is very good though not delicious ; Osyris quadridentata, Phillyrea latifolia and $P$. angustifolia, Asparagus albus, with occasionally, near Algiers, some groups of Pinus halepensis. These plants form the chief features of the vegetation of the uncultivated hills.

The natural meadows in the neighbourhood of Algiers, and indeed all the hilly parts of Barbary, afford excellent forage, being composed almost entirely of Leguminous plants, amongst which the genus Medicago holds the first rank, and is very rich in species. Different species of Scorpiurus, Astragalus, Ornithopus, Hedysarum and Onobrychis complete the list of meadow plants as far as Leguminous species are concerned. Hedysarum coronarium deserves a special notice, as it grows in immense quantities in certain districts, and is much relished by horses. This plant grows several feet high, and bears a beautiful spike of scarlet flowers : it is cultivated extensively at Malta, under the name of Silla.

In the moist and marshy plains, such as that of the Mitidja, the gramineous plants predominate, and the hay is not so much prized. The principal species are Phalaris carulescens and Dactylis glomerata, with many Junci and a few Carices in moist places. The hay harvest begins towards the end of April, and is succeeded by the cutting of barley in May, and the wheat is got in in the month of June. The principal cereal crops are barley and wheat, the former being of the variety called sixrowed; and the wheat is red wheat, which is better suited for making the national dish of couscoussou. White wheat is 
only cultivated by Europeans, and even by them on a very small scale, as all the fine flour used in the colony comes from Marseilles or other French ports. Rye is also cultivated by the colonists, but principally for its straw. A field of oats is a great rarity, as barley is the only corn given to horses. In reaping the corn the ear only is cut off, and the straw left for the cattle : what is left by them is burnt at sowing time, and the ashes afford the only manure supplied to the land. There is no preparatory tillage of the ground before sowing: the grain is thrown on the ground and ploughed in by a very simple plough drawn by oxen or horses, and sometimes by a horse and a cow yoked together. The furrows run in all directions, and by their frequently crossing one another, leave sometimes small triangular spaces unploughed.

Maize or Indian corn is only cultivated in small quantities, as it requires to be watered. The heads of maize are generally eaten before they are ripe, by being roasted on hot cinders. Broad beans are commonly cultivated in the open country. Peas and potatoes are cultivated in inclosed gardens. Potatoes are planted in September and are gathered in December; a second crop is put in in March and taken up in June; and in gardens which are easily watered, a third crop is planted in June and gathered in September. The European colonists sow large quantities of haricots or French beans, which are eaten either green or ripe, but only in the latter state by the natives: chick peas or garbanços are principally cultivated by the Spanish colonists, but the Moors and Arabs eat great quantities of them; they cook them by roasting in an oven. Artichokes are very common in the gardens, and are much used by the Moors both raw and cooked: the Arabs, who have no fixed gardens (except in some localities near springs of water), employ as a substitute for artichokes the heads of Cynara Cardunculus, which is very abundant in certain clayey soils of the Mitidja. Onions and carrots are much used, and different kinds of lettuce.

Asparagus is abundant in autuinn and spring; it is found in the hedges, and is the produce of Asparagus albus and $A$. acutifolius: the former species produces larger turions, but they are rather bitter to the taste; whilst those of $A$. acutifolius are as sweet as the cultivated $A$. officinalis : this last-named species I have discovered in the marshes of the plain of Mitidja, but I never observed the turions.

Melons are not very abundant; they are brought from Spain at so low a price that no encouragement is afforded for their cultivation. Water melons are more common, and are a valuable fruit in the warm summer months. Gourds of various kinds are cultivated in great quantities by the Arabs in those gardens which are situated near springs of water. Cucumbers are also common: 
the natives eat them as we would eat an apple, without any condiment.

A pot-herb much used in Barbary is the Hibiscus esculentus: the tender seed-vessels are cut in small pieces and boiled, or stewed with meat : it is a tasteless vegetable. Very different is the Capsicum annuum, whose pods are used abundantly : the green fruit of Capsicum grossum is eaten raw with oil and vinegar, and forms a dish, either served alone or with slices of tomato or loveapple: this last-mentioned plant is very extensively cultivated both by natives and colonists.

A great many plants are used by the Arabs to season their dishes, amongst which we may mention coriander, whose green leaves have a strong smell of bugs; both leaves and seeds are used. Parsley, basilic, sweet savory, chervil, fennel, mint, marjoram, are all in great demand. The Arabs who live in tents, and have no gardens, procure their pot-herbs from the plains, which furnish them with Cynara Cardunculus, Cynara acaulis, Atractylis gummifera (of this plant they eat the midribs of the leaves), Ammi majus, Ferula communis, Borage, and a host of other plants.

I will now mention the principal fruits properly so called: they are not so varied nor yet generally so delicious as in Europe. The apricot must hold the first rank : the tree grows without any care or even pruning, and ripens its fruit in June. There are several kinds of apricot, of which the best is one called Chachi : it is very juicy, and the flesh adheres to the stone. The kind called Boreulbi is considered very inferior ; it resembles the one commonly cultivated in England. The peach and nectarine are less abundant, although with only the care of properly pruning, and the proper choice of varieties, they would be as good as in Europe.

The fig-tree is a native of the country, and in certain districts is cultivated to a great extent. The early figs, or bakhor, ripen in June, and the second crop in August and September : it is only this last kind which is dried, the bakhor being too watery for the purpose. There are many varieties of fig, and they are all good; one kind which ripens in September and October, called Verdarola by the Spaniards, is much esteemed, as well for its luscious taste as for its late ripening. Fig-trees are propagated from branches about a yard long, stuck in the ground: these, if they live, bear fruit about the third year. Pomegranates are abundant, and the tree, when covered with scarlet flowers, is a most beautiful object : the fruit ripens in September, and may be kept through the winter. When of a good kind, it is a most delicious fruit; otherwise it is very insipid.

The jujube-tree is very common, aud the fruit ripens in Octo- 
ber: it is seldom eaten by Europeans, but the colonists sometimes make of it an agreeable kind of cider. The tree has a very remarkable appearance in winter, as most of the branches terminate in thickened clubs, instead of gradually tapering towards their extremities, like almost all other trees. These clubs appear to be reservoirs of elaborated sap, as from them proceed small annual deciduous branches which bear the fruit, the growing part of the tree being covered with strong prickles, and these branches taper like those of ordinary trees.

There are several vineyards in the neighbourhood of Algiers, but the vine was more commonly cultivated by the Arabs in the interior, as near Medeah, Milianah, Mascara, \&c. As wine is forbidden to Mussulmen, the grapes were only used for eating, and consequently in the same vineyard will be found grapes of all kinds and colours. I have tasted wine made by the Jews before the French occupation; it was a dry white wine and very spirituous. The French colonists, in the neighbourhoods of Medeah near Algiers, and Mascara near Oran, have made a considerable quantity of wine during the last few years; this wine is made from the old vineyards of the Moors, which had been neglected for many years, and become almost barren. The culture of the vine has not been sufficiently practised by the French colonists : as the plants do not produce fruit before three years, few could be found who would hazard their money for so long a period, in a country where 10 per cent. per annum is the legal rate of interest, and as high as 30,40 , or 50 per cent. are often taken. Vines, when trained on trellis-work, produce enormous crops, and of very delicious quality. The usual price of grapes in the market is about $2 d$., or 4 sous per $1 b$., whereas in the South of France $\frac{1}{2} d$. or 1 sou is a common price. Great quantities of fresh grapes are brought from Spain, and in the province of Oran, at least on the sea-coast, are the only ones to be had. Near Algiers I have often eaten the fruit of wild vines which climb the hedges, and they only differ from the cultivated grapes by their size, the flavour being equally good.

We will now mention the orange-tree and its allied species. In the immediate neighbourhood of Algiers, the bitter or Seville orange-tree was almost the only kind cultivated by the Moors, as the sweet oranges were brought from Blidah and the Mitidja, and sold at the rate of a penny a dozen; whilst the bitter orangetree was cultivated for the sake of its flowers, which are much better than those of the sweet orange-tree. There are not better oranges in the world than those of Blidah, both for size and flavour. The groves are yet very extensive, but an immense number of trees were cut down in 1840 by order of General Duvivier, as the Arabs concealed themselves amongst these trees 
to fire on the inhabitants. The usual height of orange-trees is about $30 \mathrm{ft}$., and a grove of them covered with flowers and fruit at the same time, that is, in the month of April, is a splendid sight. Lemon-trees are equally common, as are also sweet lemons or bergamots. The citron (in French cédrat) is much less common, and is only used for making preserves: the rind is more than an inch thick, and is eaten raw by the Arabs. Other varieties have been introduced by the French, such as the Chinois, a very small kind used for preserves, and the Mandoline, a very small delicious orange from Nialta introduced by Mr. St. John, English Consul in Algiers. The orange-tree is generally brought from Genoa, although some grafts are made in the country; and I possess trees sown from seeds, which after ten years' growth produced delicious oranges without grafting, not a flower having been produced before that period.

The silk mulberry-tree was not cultivated before the French occupation, but has since been planted to almost an excess;-I say excess, because their leaves are left to dry on the trees instead of being employed in the cultivation of the silk-worm. The silk produced in Algeria has been acknowledged by a commission at Lyons, appointed for the purpose of examining it, to be of a superior quality, and fetches as high a price in the market as some of the finest silks of the Cevennes. However, Algiers possesses advantages in the rearing of silk-worms which are not to be found in France. The mild temperature dispenses entirely with artificial heat, and the leaves have not to dread the late frosts which so frequently injure the trees in France. The black mulberry is cultivated by the Moors for the sake of its fruit. The caroub or locust-tree, Ceratonia Siliqua, is found wild on the hills; its wood is considered imperishable, and the fruit is sold in the shops, and eaten by the natives: in southern Spain this fruit is used very extensively for feeding horses and mules. This tree and the wild olive-tree are the largest in the country. The wild olive is the most common tree in the neighbourhood of Algiers; the fields are divided by hedges formed principally of it: the olive it produces is very small, but makes excellent oil ; its small size renders it too tedious to gather, and it is left to fall from the tree, or become the food of starlings which visit the country in winter in immense flocks. The oil consumed in Algiers is brought by the Kabyles from the mountains between Algiers and Bougia, and is the product of the grafted olive-tree.

The most ordinary food of the Arabs is bread sopped in oil, when they can get it. The sweet acorn, the product of the Quercus Ballota, which grows to a very large size, is much used as an article of food: when raw it has very much the taste of chestnuts : it is either eaten in this state or boiled: the French 
have used it roasted to imitate coffee. Chestnuts are very rare, as I have not seen a dozen trees in the country. Cherry-trees grow wild in some of the shady ravines of Boujareah near Algiers, but I never saw any fruit on them : the cherries consumed in Algiers are brought from Spain. Plums are more common, but not of a good quality. Apples are very poor, although in certain districts near Algiers a small kind of summer apple is very common. Pears are better, but there existed very few varieties until the French occupation. The loquat, or fruit of Mespilus japonica, ripens perfectly and is much esteemed; it has rather the taste of an English gooseberry: this last shrub is cultivated in a few gardens as an object of curiosity, but I never saw the red currant, although many French colonists have imported the tree, which seldom survives the first year. The service-tree, Sorbus domestica, is rather common in gardens. Strawberries have been introduced by the French, and produce fruit in gardens which have a good supply of water: in such places they are to be had at all seasons, even in December. The Moors call them tout ensàra, Christian mulberries.

There are very few gardens without a few banana or plantaintrees : the fruit ripens perfectly, but always fetches a high price. In certain parts in the interior, as Tlemcen, the walnut-tree is common, but it is rare near the coast: the bark of the root is very much used by the natives to dye their feet and hands on feastdays. Almond-trees are very common; they flower in January and ripen their fruit in September. I can scarcely count the myrtle as a fruit-tree, yet the ripe berries are much eaten, and even brought from Spain; they have a sweetish but powerfully aromatic taste, resembling juniper berries. Of the same flavour are the berries of the lentisk-tree, which are eaten by both Moors and Spaniards.

Many opinions have been given as to the fruit called Lotus, described by Herodotus, Pliny, Theophrastus, and other ancient writers, and which gave its name to a whole people, who were called Lotophagi. Some believe it to be the fruit of the Celtis australis common in the Mediterranean region; this tree however does not answer to the description of the lotus-tree, which was described as being a low prickly shrub, nor does the fruit possess the quality attributed to it, of making a man forget his country, "tam dulci ibi cibo, ut nomen etiam genti terræque dederit, nimis hospitali advenarum oblivione patriæ, \&c.” (Plin. l. 13. c. 17.) Shaw and Peyssonel fancied that it was the Ziziphus Lotus or Sidra of the Arabs: the description of the shrub agrees with that of the real lotus; but its fruit, which resembles very much that of our common hawthorn in flavour, can neither by its taste nor any other property, cause a man to forget his country. The date 
is another fruit which has been thought by its luscious flavour to be the lotus, but the sweetness of the date is the only point which agrees with the description of the fruit in question. I have received from M. Pelissier, Consul of France at Soussa, near Tripoli, specimens of a plant called Nitraria tridentata : it is a small prickly shrub agreeing in description with the lotus of the ancients, and moreover the fruit is pleasant to the taste, and has a slightly intoxicating property, quite sufficient to make a man forget his country whilst under the influence of it: it is called by the Arabs damouch. I think this plant has greater claims than any other to be the lotus, both from the description of the plant and fruit, and also from its geographical position, the region of the Lotophagi, being to the eastward of the kingdom of Algiers.

I shall only just mention the date-palm, as it is cultivated rather as an object of curiosity, at least on the littoral, than of utility: the date-eating people live many hundred miles in the interior. Cotton has been tried with success, but the high price of manual labour prevents its extensive cultivation. The sugarcane grows without care, but is not used in the making of sugar : some of the colonists are in the habit of planting it to serve as green food for the cattle in summer, when the meadows and pastures are dried up. Tobacco is cultivated both by natives and colonists : the French have lately introduced several varieties of tobacco, and have drawn the attention of the settlers to the cultivation of this plant. The variety grown by the Arabs is very mild, and resembles in a great measure the Latakia or other Oriental tobaccos. The French government have established an Experimental Garden on a large scale near the town of Algiers; and here may be seen growing, without any artificial covering, indigo, tea, coffee, sesamum, and a great number of ornamental plants, which, under an English climate, would require the protection of a stove. The Bougainvillea spectabilis flowers against a wall in February : Erythrina Crista Galli attains a height of 20 feet. Cassia tomentosa, the Guava plum, Lantana Cammara, the bamboo cane, Sparmannia africana, Justicia Adhatoda, and a host of other tropical plants, flower perfectly in the open air and are left out all winter. Except the two native species of heath, I never saw any plants of this tribe in Algeria.

The kingdom of Algiers has not any particular kind of vegetation to distinguish it from the Mediterranean region in general. Its flora is almost identical with that of the South of Spain, and of Andalusia in particular : the two species of Phelipaa which are found near Oran are remarkable by the immense size of their fleshy stems. The richest harvest for a botanist is on the low dry hills in early spring, as the meadows and plains often yield only Ann. \& Mag. N. Hist. Ser. 2. Vol. iv. 
many of the common European species. The old Roman roads which still exist in the immediate neighbourhood of Algiers are rich in rare species: under the shade of the wild olive-trees which overhang these roads are found Lycopodium complanatum, Grammitis leptophylla, Asplenium palmatum, Trachelium caruleum, Campanula dichotoma, Sedum heptapetalum, Scrophularia trifoliata and mellifera, Allium triquetrum, many Ophryses, and other interesting plants, whilst the trees themselves are festooned with Clematis cirrhosa, which is covered with flower in December, Smilax mauritanica, Convolvulus sepium, wild vine, Tamus communis, Aristolochia altissima, Rosa sempervirens, and in some parts Ephedra altissima and Equisetum ramosissimum.

The provinee of Oran affords the richest harvest of rare plants, both on the coast and in the interior. In the sandy plains of that province the Cynomorium coccineum is common, and in the brackish water lakes are found Durica helicophylla and Ruppia trichodes, two new species of plants found by M. Durieu. Near Saida is found the curious Otocarpus virgatus, a new plant of the family of Cruciferæ. This family has some very curious representatives in this province, and which are not found except in Algeria; such are Condylocarpus muricatus, Psychine stylosa, Lonchophora Capiomontiana, and Bunias prostrata. The greatest number of species of plants in Algeria may be reckoned in the family of Leguminosæ. The neightourhood of Oran furnishes several new species of Genista, such as G. cephalantha, Spach, G. Duriai, Sp., G. spartiö̈des, Sp., G. numidica, Sp., G. ulicina, Sp., G. atlantica, Sp., G. erioclada, Durieu, all of which are figured in the splendid work now publishing by the French government, upon the labours of the Scientific Commission sent to Algeria a few years ago to explore its productions in natural history. The family of Leguminose also presents us with a number of species of Medicago, some of which are new, viz. M. corrugata, Dur., $M$. plagiospira, Dur., M. secundiflora, Dur., which are figured in the work above-mentioned. In the same family we have some interesting plants amongst the pea tribe, such as Orobus atropurpureus, Desf., which covers the meadows in certain localities on the plain of Mitidja near Algiers, and flowers in April. In my catalogue of the plants of Algiers I have described a new species of Lathyrus, under the name of $L$. luteus; it climbs the hedges near Algiers, and resembles very much $L$. sylvestris, L., but its yellow flowers and filiform stipules constitute it a distinct species. Lathyrus Clymenum and L. tingitanus, L., the latter of which is commonly cultivated in our gardens under the name of Tangier pea, are both very common in the hedges and brushwood.

It was my intention to have passed in review each family of 
plants, and of pointing out the most remarkable species which occur in Algeria, but I find that it would only draw out this paper to an immeasurable length.

I cannot however pass over a new species of Stapelia, named by Decaisne Boucerosia Munbyana, and discovered by me in the neighbourhood of Oran, interesting in a geographical point of view; it is well known that the great seat of Stapelias (which is a most distinct and perfectly natural genus) is at the Cape of Good Hope, and until lately only one species occurred in Europe as a representative of this genus; I speak of Stapelia europaca, which is found in Sicily and the southern coast of Spain. The discovery of an allied species on an intermediate point is I conceive very interesting, and will in all probability form the second link in a chain which will connect the humble Stapelia europaa with the remarkable Cape species.

I shall conclude this paper by noticing a lichen called $L$. esculentus, and which agrees, at least more nearly than any other substance hitherto discovered, with the description of the Manna on which the Israelites fed during their wanderings in the desert.

This lichen is found on the sand of the desert, which it covers in some parts, and grows during the night, as do many mushrooms. The French soldiers during an expedition towards the south of Constantine actually subsisted upon it for some days, cooking it in various ways, and even making it into bread. I do not pretend to explain the miraculous portions of the history of the Manna, but it is very probable that if gathered when alive or in a soft state, it would in a very short time ferment if placed in a heap, and from the rapid development of animal life in that warm climate, "breed worms and stink" in a very few hours. Neither wonld I attempt to explain the double quantity gathered on the sixth day. The description given by Moses is this: "Upon the face of the wilderness there lay a small round thing, as small as hoar-frost on the ground "" and again, "it was like coriander seed, white ; and the taste of it was like wafers made with honey." There are a few characters in this account of it which disagree with the substance I present to you, yet the discovery of a substance springing up in the short space of a night on the surface of the sandy desert, and that substance capable of sustaining human life, is, to say the least, a remarkable fact, and one well worthy the examination and researches of botanists. 